\title{
DISCUSSION
}

\section{Site characterisation for the Ballina field testing facility}

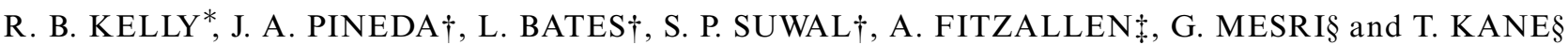

\section{Contribution by G. Mesri and T. Kane}

The comprehensive laboratory and in situ measurements reported by Kelly et al. (2017) and also by Pineda et al. (2016) on geotechnical characteristics of Ballina soft clay in New South Wales, Australia, deserve further interpretation. The stratigraphy is uniform between reduced levels of $-2 \mathrm{~m}$ to $-10 \mathrm{~m}$; therefore, this interpretation is limited to Ballina soft clay at mid-depth of $-6 \mathrm{~m}$. At this depth, plasticity index, $I_{\mathrm{p}}$, is near $70 \%$; clay size fraction, $\mathrm{CF}$, is near $70 \%$; and in situ effective vertical stress is $42 \mathrm{kPa}$. Ballina soft clay was deposited about 8000 years before present (BP) in saline water in an estuarine environment.

\section{Preconsolidation pressure}

Before introduction of the constant rate of strain consolidation test (CRS) most data on preconsolidation pressure of soft clay deposits had originated from incremental loading (IL) consolidation tests, and corresponded to an end-of-primary (EOP) $e-\log \sigma_{\mathrm{v}}^{\prime}$ relation of $20 \mathrm{~mm}$ thick specimens. Therefore, an expression was developed for strain rate imposed on the CRS test that would lead to the EOP $e-\log \sigma_{\mathrm{v}}^{\prime}$ relationship (Mesri \& Feng, 1992; Mesri et al., 1994a)

$$
\dot{\varepsilon}_{\mathrm{p}}=\frac{k_{\mathrm{v} 0}}{2^{C_{\mathrm{c}} / C_{\mathrm{k}}} H^{2}} \frac{\sigma_{\mathrm{p}}^{\prime}}{\gamma_{\mathrm{w}}} \frac{C_{\alpha}}{C_{\mathrm{c}}}
$$

where $k_{\mathrm{v} 0}$ is the initial permeability in vertical direction; $C_{\mathrm{c}} / C_{\mathrm{k}}$ has typical values of $1 / 2$ to 2 (Mesri \& Rokhsar, 1974); $H$ is maximum drainage distance; $\sigma_{\mathrm{p}}^{\prime}$ is preconsolidation pressure; $\gamma_{\mathrm{w}}$ is unit weight of water; and, for soft clays, $C_{\alpha} / C_{\mathrm{c}}=0.04 \pm 0.01$ (Terzaghi et al., 1996). An imposed vertical strain rate equal to $\dot{\varepsilon}_{\mathrm{p}}$ leads to excess pore water pressures near zero at the bottom (impermeable boundary) of a CRS specimen. For soft clay deposits, the most typical value of $\dot{\varepsilon}_{\mathrm{p}}$ is equal to $2.5 \times 10^{-7} \mathrm{~s}^{-1}$ (Mesri et al., 1994a).

An imposed vertical strain rate equal to $\dot{\varepsilon}_{\mathrm{p}}$ results in a rather long duration of the CRS test, and very small, near-zero excess pore water pressures do not allow the coefficient of permeability to be computed using the CRS porewater pressure measurements. Therefore, Mesri \& Feng (1992) proposed for the CRS test an imposed vertical strain rate

$$
\dot{\varepsilon}_{\mathrm{I}}=10 \dot{\varepsilon}_{\mathrm{p}}
$$

\footnotetext{
* SMEC Australia, Brisbane, Australia; ARC Centre of Excellence for Geotechnical Science and Engineering, The University of Newcastle, Callaghan, Newcastle, Australia; University of Wollongong, Wollongong, Australia.

$\dagger$ ARC Centre of Excellence for Geotechnical Science and Engineering, The University of Newcastle, Callaghan, Newcastle, Australia.

† Coffey Geotechnics, Chatswood, Australia.

$\S$ University of Illinois, Urbana-Champaign, IL, USA.
}

which produces $u_{\mathrm{b}}^{\prime} / \sigma_{\mathrm{v}}$ values in the range of 3-5\% (where $u_{\mathrm{b}}^{\prime}$ is the excess pore water pressure at the bottom of the specimen and $\sigma_{\mathrm{v}}$ is the imposed total vertical stress), and allows the Darcy flow equation to be used for reliable calculation of the coefficient of permeability (Mesri et al., 1994a, 1994b). However, the resulting preconsolidation pressure must be corrected to obtain EOP $\sigma_{\mathrm{p}}^{\prime}$ (Mesri \& Choi, 1979, 1984; Mesri, 1987; Terzaghi et al., 1996).

$$
\left[\sigma_{\mathrm{p}}^{\prime}\right]_{\dot{\varepsilon}_{\mathrm{p}}}=\left[\sigma_{\mathrm{p}}^{\prime}\right]_{\dot{\varepsilon}_{\mathrm{I}}}\left(\frac{\dot{\varepsilon}_{\mathrm{p}}}{\dot{\varepsilon}_{\mathrm{I}}}\right)^{C_{\alpha} / C_{\mathrm{c}}}
$$

For Ballina clay, the value of $\sigma_{\mathrm{p}}^{\prime} / \sigma_{\mathrm{v} 0}^{\prime}$ is near 1.77 from the CRS oedometer data in Fig. 4(b). However, the imposed strain rate was $3.3 \times 10^{-6} \mathrm{~s}^{-1}$ for the CRS tests on Ballina soft clay, compared to $\dot{\varepsilon}_{\mathrm{p}}=3.4 \times 10^{-7} \mathrm{~s}^{-1}$ from equation (2) for $k_{\mathrm{vo}}=10^{-9} \mathrm{~m} / \mathrm{s}, C_{\mathrm{k}} / C_{\mathrm{c}}=1, C_{\alpha} / C_{\mathrm{c}}=0.04$ and $\sigma_{\mathrm{p}}^{\prime}=68 \mathrm{kPa}$. Therefore, using equation (4) together with $C_{\alpha} / C_{\mathrm{c}}=0 \cdot 04$, leads to $\sigma_{\mathrm{p}}^{\prime} / \sigma_{\mathrm{vo}}^{\prime}=1 \cdot 61$, and for $\sigma_{\mathrm{v} 0}^{\prime}=42 \mathrm{kPa}$, to $\sigma_{\mathrm{p}}^{\prime}=68 \mathrm{kPa}$.

For cone penetration tests, according to Mesri (2001)

$$
\sigma_{\mathrm{p}}^{\prime}=0 \cdot 28\left(q_{\mathrm{t}}-\sigma_{\mathrm{v}}\right)
$$

From the cone penetration tests on Ballina clay, at $-6 \mathrm{~m}$, $q_{\mathrm{t}}=327 \mathrm{kPa}$ and $\sigma_{\mathrm{v}}=100 \mathrm{kPa}$ lead to $\sigma_{\mathrm{p}}^{\prime}=64 \mathrm{kPa}$.

For a geologically normally consolidated clay, the value of $\sigma_{\mathrm{p}}^{\prime} / \sigma_{\mathrm{v} 0}^{\prime}$ resulting from secondary compression and thixotropic ageing alone is (Mesri \& Choi, 1979, 1985; Mesri, 1993)

$$
\frac{\sigma_{\mathrm{p}}^{\prime}}{\sigma_{\mathrm{v} 0}^{\prime}}=\left(\frac{t}{t_{\mathrm{p}}}\right)^{\left[\left(C_{\alpha} / C_{\mathrm{c}}\right) / 1-\left(C_{\mathrm{r}} / C_{\mathrm{c}}\right)\right]+\beta}
$$

Using $t=8000$ years, $t_{\mathrm{p}}=10$ years, $C_{\alpha} / C_{\mathrm{c}}=0 \cdot 04, C_{\mathrm{r}} / C_{\mathrm{c}}=0 \cdot 1$, and thixotropic hardening parameter $\beta=0.02$, it is possible to calculate $\sigma_{\mathrm{p}}^{\prime} / \sigma_{\mathrm{v} 0}^{\prime}=1 \cdot 53$. The difference between 1.61 and 1.53 has probably resulted from groundwater fluctuations.

\section{Undrained shear strength}

For Ballina clay, the undrained shear strength was estimated from field vane tests (FV), triaxial compression tests (TC) and triaxial extension tests (TE). At $-6 \mathrm{~m}$ depth, the value of $s_{\text {uo }}$ $(\mathrm{FV})$ is $20 \cdot 0 \mathrm{kPa}$ from Fig. 15. Thus $s_{\mathrm{uo}}(\mathrm{FV}) / \sigma_{\mathrm{p}}^{\prime}=0 \cdot 294$. However, from the Bjerrum-Mesri $s_{\mathrm{uo}}(\mathrm{FV}) / \sigma_{\mathrm{p}}^{\prime}$ against $I_{\mathrm{p}}$ relationship, for $I_{\mathrm{p}}=70 \%, s_{\mathrm{u} 0}(\mathrm{FV}) / \sigma_{\mathrm{p}}^{\prime}=0.32$ (Terzaghi et al., 1996, fig. 20 20). For Ballina clay at $-6 \mathrm{~m}$ depth $s_{\mathrm{uo}}(\mathrm{TC}) / \sigma_{\mathrm{p}}^{\prime}$ is $0 \cdot 300$, and $s_{\mathrm{uo}}(\mathrm{TE}) / \sigma_{\mathrm{p}}^{\prime}$ is $0 \cdot 263$.

The undrained shear strength mobilised in failure of embankments, footings and excavations is

(a) Bjerrum $(1972,1973)$ with Bjerrum correction $\mu_{\mathrm{B}}=0 \cdot 70$ for $I_{\mathrm{p}}=70 \%$ (Terzaghi et al., 1996, fig. 20·21).

$$
\begin{aligned}
\frac{s_{\mathrm{u} 0}(\mathrm{mob})}{\sigma_{\mathrm{p}}^{\prime}} & =\mu_{\mathrm{B}} \frac{s_{\mathrm{u} 0}(\mathrm{FV})}{\sigma_{\mathrm{p}}^{\prime}} \\
& =0 \cdot 21 \\
s_{\mathrm{u} 0}(\mathrm{mob}) & =0 \cdot 21 \times 68=14.3 \mathrm{kPa}
\end{aligned}
$$


(b) Mesri (1975), for inorganic soft clays

$$
\frac{s_{\mathrm{u} 0}(\mathrm{mob})}{\sigma_{\mathrm{p}}^{\prime}}=0.22
$$

$s_{\mathrm{u} 0}(\mathrm{mob})=0 \cdot 22 \times 68=15 \cdot 0 \mathrm{kPa}$

(c) Mesri (2001), mobilised undrained shear strength from cone penetration test

$$
s_{\mathrm{u} 0}(\mathrm{mob})=\frac{q_{\mathrm{t}}-\sigma_{\mathrm{v}}}{N_{\mathrm{k}}(\mathrm{mob})}
$$

where $q_{\mathrm{t}}$ is the corrected cone tip resistance, $\sigma_{\mathrm{v}}$ is the total vertical stress and $N_{\mathrm{k}}(\mathrm{mob})=16$.

$$
s_{\mathrm{u} 0}(\mathrm{mob})=\frac{327-100}{16}=14 \cdot 2 \mathrm{kPa}
$$

(d) Mesri (1989) and Mesri \& Huvaj (2007) mobilised undrained shear strength from laboratory tests. In the absence of $s_{\mathrm{u} 0}(\mathrm{DSS}) / \sigma_{\mathrm{p}}^{\prime}$

$$
\frac{s_{\mathrm{u} 0}(\mathrm{mob})}{\sigma_{\mathrm{p}}^{\prime}}=\frac{1}{2}\left[\frac{s_{\mathrm{u} 0}(\mathrm{TC})}{\sigma_{\mathrm{p}}^{\prime}}+\frac{s_{\mathrm{u} 0}(\mathrm{TE})}{\sigma_{\mathrm{p}}^{\prime}}\right] \mu_{\mathrm{t}}
$$

where $\mu_{\mathrm{t}}$ is a time to failure correction factor as a function of plasticity index, $I_{\mathrm{p}}$, equal to 0.83 for $I_{\mathrm{p}}=70 \%$ (Terzaghi et al., 1996, fig. 20·24).

Note that shear strength from laboratory tests from Jamiolkowski et al. (1985) and Ladd (1991) have been incorrectly reproduced in Fig. 21.

$$
\begin{aligned}
\frac{s_{\mathrm{u} 0}(\mathrm{mob})}{\sigma_{\mathrm{p}}^{\prime}} & =\frac{1}{2}(0.300+0.263) 0.83 \\
& =0.23 \\
s_{\mathrm{u} 0}(\mathrm{mob}) & =0.23 \times 68=15.6 \mathrm{kPa}
\end{aligned}
$$

Therefore, for Ballina soft clay at $-6 \mathrm{~m}$ depth, the most typical value of $s_{\mathrm{uo}}(\mathrm{mob}) / \sigma_{\mathrm{p}}^{\prime}=0 \cdot 22$, and $s_{\mathrm{uo}}(\mathrm{mob})=15 \mathrm{kPa}$.

\section{Coefficient of earth pressure at rest}

According to Fig. 11(d), $K_{0}=0 \cdot 560$, and according to Fig. $13, \phi_{\mathrm{cv}}^{\prime}=34^{\circ}$, where $\phi_{\mathrm{cv}}^{\prime}$ is the constant volume friction angle (Terzaghi et al., 1996).

The Schmidt (1967) equation for $K_{0}=\sigma_{\mathrm{h} 0}^{\prime} / \sigma_{\mathrm{v} 0}^{\prime}$ is (Mesri \& Hayat, 1993)

$$
K_{0}=K_{0 \mathrm{p}}\left(\frac{\sigma_{\mathrm{p}}^{\prime}}{\sigma_{\mathrm{v} 0}^{\prime}}\right)^{\sin \phi_{\mathrm{cv}}^{\prime}}
$$

where $K_{0 \mathrm{p}}$ is the coefficient of lateral pressure in the compression range beyond $\sigma_{\mathrm{p}}^{\prime}$, and according to Jaky (1948)

$$
K_{0 \mathrm{p}}=1-\sin \phi_{\mathrm{cv}}^{\prime}
$$

thus $K_{0 \mathrm{p}}=0.4408$ and $K_{0}=0.575$.

The Mesri \& Hayat (1993) equation for $K_{0}$ of soft clay and silt deposits is

$$
K_{0}=\frac{1}{2} K_{0 \mathrm{p}}\left(\frac{\sigma_{\mathrm{p}}^{\prime}}{\sigma_{\mathrm{v} 0}^{\prime}}+1\right)
$$

using $K_{0 \mathrm{p}}=0.4408$ and $\sigma_{\mathrm{p}}^{\prime} / \sigma_{\mathrm{v} 0}^{\prime}=1.61, K_{0}=0.575$.

Thus the predictions of $K_{0}=\sigma_{\mathrm{h} 0}^{\prime} / \sigma_{\mathrm{v} 0}^{\prime}$ by Schmidt (1967) and Mesri \& Hayat (1993) empirical equations are in agreement with values reported in Fig. 11(d).

\section{Compressibility}

The compressibility of soft clay deposits is completely defined by the EOP $e-\log \sigma_{\mathrm{v}}^{\prime}$ relationship of each sublayer, and $C_{\alpha} / C_{\mathrm{c}}$. For strongly non-linear EOP $e-\log \sigma_{\mathrm{v}}^{\prime}$ relations in the compression range beyond $\sigma_{\mathrm{p}}^{\prime}$, such as those for Ballina clay in figs 6 and 7 of Pineda et al. (2016), the values of tangent compression index, $C_{\mathrm{c}}$, such as those in Fig. 9 of the paper under discussion cannot be readily incorporated into a simple settlement equation. The strongly non-linear compression curve is best described in terms of values of secant compression index, $C_{\mathrm{c}}^{\prime}$, as a function of $\log \sigma_{\mathrm{v}}^{\prime} / \sigma_{\mathrm{p}}^{\prime}$ (Mesri \& Choi, 1985, Terzaghi et al., 1996: figs $16 \cdot 16$ and $16 \cdot 7$, equation (16.9); Mesri \& Funk, 2015: figs 7 and 8).

The values of $C_{\alpha} / C_{\mathrm{c}}$ for Ballina soft clay are within the range of $0.04 \pm 0.01$ for soft clay and silt deposits (Terzaghi et al., 1996, table 16.1). Because, in the recompression range $C_{\alpha}$ increases with time, frequently, an incorrect value of $C_{\mathrm{c}}$ is paired with $C_{\alpha}$, thus resulting in high values of $C_{\alpha} / C_{\mathrm{c}}$ as in fig. 12 of Pineda et al. (2016).

\section{Coefficients of permeability and consolidation}

According to Fig. 18(b) a typical value of $k_{\mathrm{v}}$ is $10^{-9} \mathrm{~m} / \mathrm{s}$ for Ballina soft clay, which is also the most common $k_{\mathrm{v} 0}$ for soft clay deposits. An empirical equation for $k_{\mathrm{v} 0}$ (Mesri et al., 1994b), in terms of $e_{0} / \mathrm{CF}$ and activity, $A_{\mathrm{c}}=I_{\mathrm{p}} / \mathrm{CF}$, for $e_{0}=3 \cdot 0, \mathrm{CF}=70 \%$ and $A_{\mathrm{c}}=1 \cdot 0$, predicts $k_{\mathrm{v} 0}=1.4 \times 10^{-9} \mathrm{~m} / \mathrm{s}$. However, for Ballina soft clay, the value of $C_{\mathrm{k}}$ is near 1.0, based on data in fig. 11(b) of Pineda et al. (2016), whereas for most soft clays $C_{\mathrm{k}}$ is close to $e_{0} / 2$, which for Ballina soft clay is 1.5 (Tavenas et al., 1983; Mesri et al., 1994b). According to Fig. 4(d) a typical value of $c_{\mathrm{v}}$ for Ballina soft clay is $3 \mathrm{~m}^{2} /$ year, which is a common value for many soft clays; however, the lower range of $0.3-0.5 \mathrm{~m}^{2} /$ year is more consistent with the Ballina soft clay liquid limit of $110 \%$.

In summary, the observed behaviour of Ballina soft clay, in general, is remarkably consistent with those of most soft clay deposits. Therefore, an excellent selection has been made for a field testing facility in Australia.

\section{Authors' reply}

The authors would like to thank Professor Mesri and $\mathrm{Mr}$ Kane (the discussion contributors) for their valuable contribution to the analysis of the behaviour of Ballina clay. In this reply the authors wish to provide some additional information and clarifications on the points raised by the discussion contributors.

To facilitate the discussion, the authors also refer to the interpretation of the information presented in Kelly et al. (2017) and Pineda et al. (2016) by academics and practitioners, to predict the behaviour of a trial embankment built on Ballina clay improved by prefabricated vertical drains. These predictions were presented in a symposium organised by the ARC Centre of Excellence for Geotechnical Science and Engineering in Newcastle (Australia) in September 2016 (CGSE, 2016). One lesson learned from this symposium was that the interpretation of the same set of laboratory and in situ data by different predictors may result in large variations in adopted soil properties, even among experienced predictors who used the same analysis approach. Hence the authors believe that it is worth elaborating more on the derivation of some key Ballina clay parameters, in the light of the discussion contributors' analysis and limited additional data. Detailed outcomes of the above-mentioned symposium will be reported in a special issue to be published in Computers and Geotechnics later in 2017. Note that, in the following, the same notation is used as employed by the discussion contributors, for the purpose of consistency. 


\section{Preconsolidation pressure}

The discussion contributors have estimated values of preconsolidation pressure using three different methods proposed by Professor Mesri and his co-workers. Values reported by Pineda et al. (2016) (Table 2) were obtained at strain rates larger than the value imposed during IL tests which, for soft clays, typically ranges between $1.0 \times 10^{-7} \mathrm{~s}^{-1}$ (Watabe et al., 2012) and $2.5 \times 10^{-7} \mathrm{~s}^{-1}$ (Mesri et al., 1994a; Terzaghi et al., 1996). Although a correction factor was suggested based on the work by Watabe et al. (2012), uncorrected values were intentionally reported in Pineda et al. (2016), allowing the predictors to make their own estimates.

Most of the predictors did not account for rate effects and that was, in the authors' opinion, a major contributor to under-prediction of embankment settlement. The authors attribute this to some of the predictors not being familiar with the interpretation of the CRS test. For the depth analysed by the discussion contributors $(5 \cdot 5<z<6 \mathrm{~m})$, the corrected preconsolidation pressure leads to $\sigma_{\mathrm{p}}^{\prime} / \sigma_{\mathrm{v} 0}^{\prime}=1.49$ (similar to the lower bound estimated by the discussion contributors). Fig. 23(a) presents recent measurements from a creep-IL test carried out on a Sherbrooke (block) specimen obtained from borehole BH1 (depth 5.24-5.61 m), drilled $100 \mathrm{~m}$ north from borehole inclo 2. The results shown in Fig. 23 were obtained from long-term loading steps (14 days), and the maximum vertical effective stress reached was $500 \mathrm{kPa}$. Small loading increments were applied in order to obtain reliable estimates of the preconsolidation pressure. Fig. 23(b) shows the $\varepsilon_{\mathrm{v}}-\log \sigma_{\mathrm{v}}^{\prime}$ curves for constant rates of strain between $10^{-8}$ and $10^{-6} \mathrm{~s}^{-1}$, back-analysed from the creep test following the procedure described by Leroueil et al. (1985). The preconsolidation pressure ranges from $57 \mathrm{kPa}$ to $68 \mathrm{kPa}$ for strain rates of $10^{-8} \mathrm{~s}^{-1}$ and $10^{-6} \mathrm{~s}^{-1}$, respectively, and a value of $\sigma_{\mathrm{p}}^{\prime} \approx 62 \mathrm{kPa}$ is obtained for a strain rate equal to $10^{-7} \mathrm{~s}^{-1}$. This value is in agreement with the lower bound estimate proposed by the discussion contributors, as well as with the values reported in Pineda et al. (2016), once corrected by rate effects.

\section{Undrained shear strength}

The discussion contributors are right in the fact that laboratory tests from Jamiolkowski et al. (1985) and Ladd (1991) have been incorrectly replicated in Fig. 21. Owing to an error when digitising the corresponding figures, values of $s_{\mathrm{u}} / \sigma_{\text {yield }}^{\prime}$ as well as the trend lines were unintentionally shifted down compared with the original data. The corrected Fig. 24 presents the original test results together with triaxial data obtained from Ballina clay. Note that the general trends remain unchanged, but the triaxial extension tests from Ballina clay lie below the trend line drawn by Ladd (1991).

\section{Coefficient of earth pressure at rest}

Various approaches have been used to estimate the coefficient of earth pressure at rest from seismic dilatometer tests (Marchetti, 1980; Powell \& Uglow, 1988; Lacasse \& Lunne, 1988; Kouretzis et al., 2015). A range of $K_{0}$ profiles were obtained from each interpretation method, including independent estimations from a self-boring pressuremeter test (Gaone et al., 2016). Interpretation of push-in pressure cell (PiPCs) measurements showed good agreement with the lower bound profiles obtained using the expressions proposed by Lacasse \& Lunne (1988) and Kouretzis et al. (2015). Independent checks were made using similar expressions to those presented by the discussion contributors. From the analysis of the triaxial compression tests, a constant volume friction angle equal to $36^{\circ}$ was adopted. This value is similar

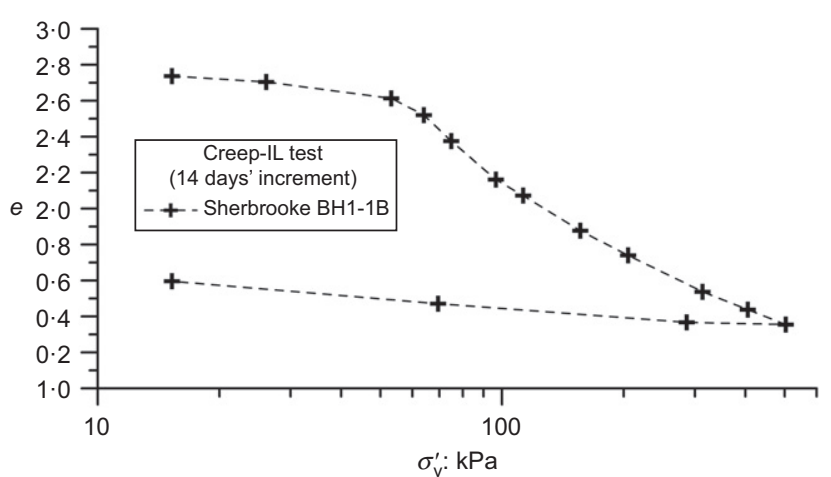

(a)

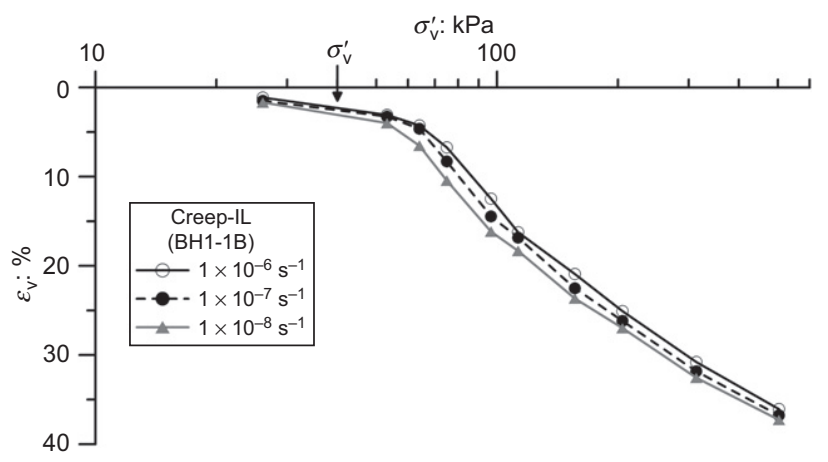

(b)

Fig. 23. One-dimensional creep test on Sherbrooke specimen BH1_1B

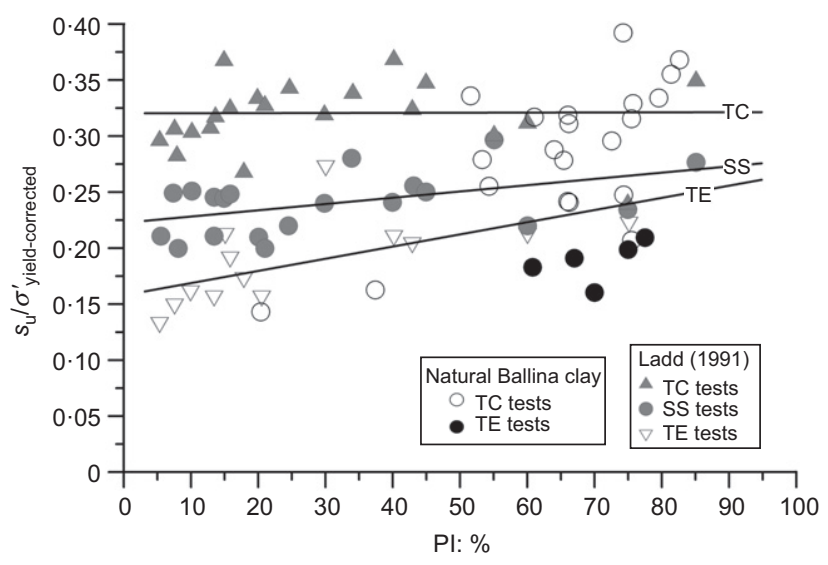

Fig. 24. Variation of normalised $s_{\mathrm{u}}$ with PI (corrected). TC, triaxial compression; TE, triaxial extension; SS, simple shear

to the constant volume friction angle reported by Mayne (2016) for a wide range of natural soft soils. A comprehensive laboratory study using high-quality Sherbrooke (block) specimens is currently underway at the University of Newcastle in order to assess $K_{0}$ for Ballina clay specimens corresponding to various depths.

\section{Compressibility}

The authors agree with the discussion contributors that the strongly non-linear compressibility curves should be incorporated into settlement assessments - for example, using secant values of $C_{\mathrm{c}}$ over the appropriate stress range as proposed by Mesri \& Choi (1985). For the prediction of the trial embankment behaviour, most symposium contributors adopted conventional bi-linear void ratio-log stress curves in 
their analyses and used 'average' $C_{\mathrm{c}}$ values based on their own judgement. Although a wide range of values was finally employed by the various predictors, there was a tendency to use values measured at stress levels much higher than the one imposed by the embankment (excluding analyses where advanced constitutive models incorporating destructuration effects were employed). In the authors' opinion, this also contributed to under-prediction of embankment settlement. The authors agree with the discussion contributors that explicitly accounting for destructuration is preferable to the use of average values and judgement, particularly when high-quality laboratory tests are available.

\section{REFERENCES}

Bjerrum, L. (1972). Embankment on soft ground. Proceedings of ASCE conference on performance of earth and earth-supported structures, vol. 2, pp. 1-54. West Lafayette, IN, USA: Purdue University Press.

Bjerrum, L. (1973). Problems of soil mechanics and construction on soft clays. Proceedings of 8th international conference on soil mechanics and foundation engineering, Moscow, USSR, vol. 3, pp. 111-159.

CGSE (Australian Research Council Centre of Excellence for Geotechnical Science and Engineering) (2016). Proceedings of the embankment prediction symposium, Newcastle, Australia. Callaghan, NSW, Australia: CGSE, The University of Newcastle. See http://cgse.edu.au/eps2016 (accessed 04/08/2017).

Gaone, F. M., Doherty, J. P. \& Gourvenec, S. M. (2016). Self-boring pressuremeter tests at the National Field Testing Facility, Ballina, NSW. In Geotechnical and geophysical site characterisation 5 (eds B. M. Lehane, H. E. Acosta-Martínez and R. Kelly), vol. 1, pp. 761-765. Sydney, Australia: Australian Geomechanics Society.

Jaky, J. (1948). Pressure in silos. Proceedings of the 2nd international conference on soil mechanics and foundation engineering, Rotterdam, the Netherlands, vol. 1, pp. 103-107.

Jamiolkowski, M., Ladd, C. C., Germaine, J. T. \& Lancellotta, R. (1985). New developments and laboratory testing of soils. In Proceedings of the 11th international conference on soil mechanics and foundation engineering, vol. 1, pp. 57-153. Boca Raton, FL, USA: CRC Press.

Kelly, R. B., Pineda, J. A., Bates, L., Suwal, L. P. \& Fitzallen, A. (2017). Site characterisation for the Ballina field testing facility. Géotechnique 67, No. 4, 279-300, http://dx.doi.org/10. 1680/jgeot.15.P.211.

Kouretzis, G. P., Ansari, Y., Pineda, J., Kelly, R. \& Sheng, D. (2015). Numerical evaluation of clay disturbance during blade penetration in the flat dilatometer test. Géotechnique Lett. 5, No. 3, 91-95.

Lacasse, S. \& Lunne, T. (1988). Calibration of dilatometer correlations. In Penetration testing, 1988: proceedings of the first international symposium on penetration testing, ISOPT-1 (ed. J. de Ruiter), vol. 1, pp. 539-548. Rotterdam, the Netherlands: Balkema.

Ladd, C. C. (1991). Terzaghi Lecture - stability evaluation during staged construction. J. Geotech. Engng 117, No. 4, 540-615.

Leroueil, S., Kabbaj, M., Tavenas, F. \& Bouchard, B. (1985). Stress-strain-strain rate relation for the compressibility of sensitive natural clays. Géotechnique 35, No. 2, 159-180, http://dx.doi.org/10.1680/geot.1985.35.2.159.

Marchetti, S. (1980). In situ tests by flat dilatometer. J. Geotech. Engng Div. ASCE 106, No. GT3, 299-321.

Mayne, P. W. (2016). Evaluating effective stress parameters and undrained shear strength of soft-firm clays from $\mathrm{CPTu}$ and DMT. Keynote Lecture. In Geotechnical and geophysical site characterisation 5 (eds B. M. Lehane, H. E. Acosta-Martinez and R. Kelly), vol. 1, pp. 19-39. Sydney, Australia: Australian Geomechanics Society.

Mesri, G. (1975). New design procedure for stability of soft clays. Discussion. J. Geotech. Engng, ASCE 101, No. 4, 409-412.

Mesri, G. (1987). Fourth law of soil mechanics: a law of compressibility. Proceedings of the international symposium on geotechnical engineering of soft soils, Mexico City, Mexico, vol. 2, pp. 179-187.

Mesri, G. (1989). A re-evaluation of $s_{\mathrm{u}}(\mathrm{mob})=0.22 \sigma_{\mathrm{p}}^{\prime}$ using laboratory shear tests. Can. Geotech. J. 26, No. 1, 162-164.

Mesri, G. (1993). Aging of soils, Invited Lecture. Proceedings of simposio sobre envejecimiento de suelos, Mexico City, Mexico, pp. $1-29$.

Mesri, G. (2001). Undrained shear strength of soft clays from push cone penetration test. Géotechnique 51, No. 2, 167-168. http://dx.doi.org/10.1680/geot.2001.51.2.167.

Mesri, G. \& Choi, Y. K. (1979). Discussion: Strain rate behavior of Saint-Jean Vianney clay, by Vaid et al. Can. Geotech. J. 16, No. $4,831-834$.

Mesri, G. \& Choi, Y. K. (1984). Discussion: Time effects on the stress-strain behavior of natural soft clays. Géotechnique 34, No. 3, 439-442.

Mesri, G. \& Choi, Y. K. (1985). Settlement analysis of embankments on soft clays. J. Geotech. Engng Div., ASCE 111, No. 4, 441-464.

Mesri, G. \& Feng, T. W. (1992). Constant rate of strain consolidation testing of soft clays. In Raul J. Marsal volume (eds E. Ovando, G. Auvinet, W. Paniagua and J. Díaz), pp. 49-59. Mexico City, Mexico: Sociedad Mexicana de Mecánica de Suelos.

Mesri, G. \& Funk, J. R. (2015). Settlement of Kansai International Airport Islands. J. Geotech. Geoenviron. Engng 141, No. 2, 1-16.

Mesri, G. \& Hayat, T. M. (1993). The coefficient of earth pressure at rest. Can. Geotech. J. 30, No. 4, 647-666.

Mesri, G. \& Huvaj, N. (2007). Shear strength mobilized in undrained failure of soft clay and silt deposits. In Advances in measurement and modeling of soil behaviour (eds D. J. DeGroot, C. Vipulanandan, J. A. Yamamuro, V. N. Kaliakin, P. V. Lade, M. Zeghal, U. El Shamy, N. Lu and C. R. Song), Geotechnical Special Publication No. 173, pp. 1-22. Reston, VA, USA: American Society of Civil Engineers (ASCE).

Mesri, G. \& Rokhsar, A. (1974). Theory of consolidation for clays. J. Geotech. Engng Div., ASCE 100, No. GT8, 889-904.

Mesri, G., Lo, D. O. K. \& Feng, T. W. (1994a). Settlement of embankments on soft clays, Keynote Lecture. In Settlement '94 (eds A. T. Yeung and G. Y. Felio), Geotechnical Special Publication No. 40, pp. 8-56. New York, NY, USA: American Society of Civil Engineers.

Mesri, G., Feng, T. W., Ali, S. \& Hayat, T. M. (1994b). Permeability characteristics of soft clays. Proceedings of the 13th international conference on soil mechanics and foundation engineering, New Delhi, India, vol. 2, pp. 187-192.

Pineda, J. A., Suwal, L., Kelly, R. B., Bates, L. \& Sloan, S. W. (2016). Characterization of the Ballina clay. Géotechnique 66, No. 7, 556-577, http://dx.doi.org/10.1680/jgeot.15.P.181.

Powell, J. J. M. \& Uglow, I. M. (1988). The interpretation of Marchetti dilatometer tests in UK clays. In Penetration testing in the UK, pp. 269-273. London, UK: Thomas Telford.

Schmidt, B. (1967). Lateral stresses in uniaxial strain. In Bulletin 23, pp. 5-12. Copenhagen, Denmark: Geoteknisk Institut (The Danish Geotechnical Institute).

Tavenas, F., Leblond, P., Jean, P. \& Leroueil, S. (1983). The permeability of natural soft clays. Part II: Permeability characteristics. Can. Geotech. J. 20, No. 4, 629-644.

Terzaghi, K., Peck, R. B. \& Mesri, G. (1996). Soil mechanics in engineering practice, 3rd edn. New York, NY, USA: Wiley.

Watabe, Y., Udaka, K., Nakatani, Y. \& Leroueil, S. (2012). Long term consolidation behaviour interpreted with isotache concept for worldwide clays. Soils Found. 52, No. 3, 449-464. 